\title{
Nile-Trophic Diatom Index (TDI-Nile): a new constructed index for assessment eutrophication in River Nile basine in Egypt
}

\author{
Mohamad S. Abd El-Karim*1, Om Mohamed A. Khafagi ${ }^{2}$ and Dalia M. Belal ${ }^{1}$ \\ 1- National Institute of Oceanography and Fisheries, 101 El Kaser Einy St., Cairo, Egypt \\ 2- Faculty of Science, Al Azhar Univ. (Girls), Nasr City, Cairo, Egypt \\ *Corresponding author
}

\begin{abstract}
In the present study, a new index (Nile-Trophic Diatom Index ,TDI-Nile) was constructed for the assessment of eutrophication in River Nile and its branches in Egypt depending on using the total phosphorus (TP), total inorganic nitrogen (TIN) and diatoms. Epilithic diatom samples wee collected from 40 locations during autumn-2013 and spring2014. Over 224 diatom taxa were identified and 91 taxa (frequency $\geq 3$ ) were sufficiently abundant to include in index development.

Multivariate data exploration revealed strong responses of the diatom assemblages to stressor variables, including total phosphorus (TP). Weighted average method was used to develop the TP and TIN indices. According to Nile-Trophic Diatom Index (TDI-Nile), most of the samples which classified in bad quality were belonging to Rosetta branch and Kema station.

Canonical correlation analysis revealed that the newly developed indices significantly well correlated (Canonical correlation $=0.79, p<0.0001$ ) with environmental variables which make them reliable indices of water quality and they can be suggested as the best indices for monitoring purposes in the River Nile.
\end{abstract}

Key words: River Nile, Water quality assessment, Nile-Trophic Diatom Index, TDI-Nile.

\section{INTRODUCTION}

The typical method for biomonitoring of freshwater quality is largely based on bioindicators, which are highly useful, especially diatoms in biomonitoring and recording biological responses, so the bioindicators are valuable in measurements of abiotic stressors (Stevenson and Smol, 2002). Developing effective indicators of ecological condition requires that indicators can be calibrated to identify their responses to important environmental stressors (Niemi and McDonald, 2004; Karr and Chu, 2000; Seegert, 2001). The main goals of calibration are to identify environmental optima and tolerances of indicator taxa, and to define systems with similar biota that respond similarly to anthropogenic stresses ( Radar and Shiozawa, 2001).

Many of diatom indices were developed to demonstrate the ability of diatom to infer water quality as Descy's Index or DES (Descy, 1979), the Specific Pollution Sensitivity Index or SPI (Cemagref, 1982), the Biological Diatom Index or BDI (Lenoir and Coste, 1996), the Eutrophication/ Pollution Index or EPI (Dell'Uomo, 1996), Sladecek's Index or SLA (Sladecek, 1986), the Trophic Diatom Index or TDI (Kelly and Whitton, 1995) and the Watanabe Index or WAT (Watanabe et al., 1986 ; Watanabe, 1990). These indices are generally based on species and sub-species levels identifications, with the exception of a few based on genus-level identifications (Rumeau and Coste, 1988; Wu, 1999; Chessman et al., 1999). These indices differ in respect to diatom species included in the calculation and the applicability of most indices has been limited in some cases, especially for rivers, since distribution of species may differ markedly (Potapova and Charles, 2007). 


\section{Mohamad S. Abd El-Karim et al.}

The effectiveness of the application of diatom index, developed in certain country, at another area was a subject of study of many authors. However, existing indices must be tested when applied to a basin different from the ones where it erected (Prygiel et al., 1999). This testing is usually done by comparing the values given by the indexes with the physicochemical data from the same sites. The Spearman correlation between an index and chemical variables is enough to determine whether that index can be applied to the basin or not. There are many studies regarding this issue and it has been proved that these indexes are applicable and work in different parts of the world (Torrisi and Dell'Uomo, 2006; Atazadeh et al., 2007; Taylor et al., 2007). On the other hand, the application of previously developed indices was not acceptable for other authors ( Descy and Ector, 1996; Kelly et al., 1998; Pipp, 2002; Rott et al., 2003; Szulc and Szulc, 2013) where these indices assessed the streams with incompatible data to the real state.

In River Nile, Belal (2012) applied four diatom indices to assess water quality in the River Nile from Aswan to Cairo, Trophic Diatom Index (TDI), Eutrophication Pollution Index (EPI), the Pampean Diatom Index (IDP) and the pollution tolerance index (PTI). However, the applications of these indices were not effective to represent the actual status of the River Nile. So, the need for the development of unique diatom index specific to the River Nile region was necessary and is the aim of this study.

\section{MATERIALS AND METHODS}

Site description, sampling, environmental conditions, diatom permanent slides preparation and diatoms identifications and counting were represented in details in Abd ElKarim et al. (2016.). In brief, the present study covered the area from Aswan Old Reservoir $\mathrm{N} 24^{\circ} 02^{\prime} 1^{\prime \prime} \mathrm{E} 32^{\circ} 51^{\prime} 57^{\prime \prime}$ passing its bifurcation at El-Kanater Barrage N 30 10' $25^{\prime \prime}$ and E $31^{\circ} 8^{\prime} 20^{\prime \prime}$, and its two main branches Rosetta and Damietta. Forty sites were selected for representing the different ecological areas of the river and most of the pollution sources. These sites were visited during autumn-2013 and spring-2014 and water samples for chemical (Nitrogen-Nitrate, Nitrogen-Ammonium, Nitrogen-Nitrite, soluble reactive meaurments of phosphorus, total phosphorus, reactive silicate and biochemical oxygen demand) were taken as well as biological samples of epilithic diatom were collected. In situ, water temperature, $\mathrm{pH}$, electric conductivity, dissolved oxygen and total dissolved salts were measured.

The homogenized gravels samples were digested using conc. nitric and sulphuric acids in a tightly closed $100 \mathrm{ml}$ tephlon bottles, heated until all organic matter had been oxidized. The digested samples were prepared on permanent slides using a high refractive index medium (Naphrax) according to the Academy of Natural Sciences (ANS, 2002). Hereafter diatoms valves were identified and counted using an inverted microscope (Zeiss, Axiovert 25C). For chemical variables, water samples were analyzed according to APHA (2005).

\section{Species optimum and tolerance}

A species optimum represents the environmental variable concentration at which that species is most abundant. A species tolerance represents the range of environmental variable concentrations around the optimum from sites in which the species may be found. The species optimum and tolerance were calculated according to the weighted average method of Birks et al. (1990) using C2 software version 1.7.3 (Juggins, 2003).

The weighted average optimum $\left(\mathrm{U}_{\mathrm{k}}\right)$ :

$\mathrm{U}_{\mathrm{k}}=\sum_{\mathrm{ni}=1} \mathrm{Y}_{\mathrm{ik}} \mathrm{X}_{\mathrm{i}} / \Sigma_{\mathrm{ni}=1} \mathrm{Y}_{\mathrm{ik}}$

The weighted average species tolerance: 

eutrophication in River Nile basine in Egypt

$T_{k}=\sqrt{ }\left[\Sigma_{n i=1} Y_{i k}\left(X_{i}-U_{k}\right)^{2} / \Sigma_{n i=1} Y_{i k}\right]$

$\mathrm{Y}_{\mathrm{ik}}$ is the abundance of taxon $\mathrm{K}$ in sample $\mathrm{i}$,

$\mathrm{X}_{\mathrm{i}}$ is the value of environmental variable in sample $\mathrm{i}$.

The weighted average estimated optima and tolerances for total phosphorus (TP) and total inorganic nitrogen (TIN) were determined to only those species which occurred in at least three samples (frequency $\geq 3$ ). Calculation of Nile-Trophic Diatom Index (TDI-Nile) was carried out by using the weighted average equation of Zelinka and Marvan (1961):

$$
\text { TDI-Nile }=\sum_{j=1}^{n} \text { ajsjij } / \sum_{j=1}^{n} a j s j
$$

where

$a j=$ abundance (proportion) of species $\mathrm{j}$ in sample,

$i j=$ indicator value $(0-5)$ and

$s j=$ pollution sensitivity (1-3) of species $j$.

\section{Data analysis}

Pearson correlation was used to determine the relationship between the diatom indices scores and the measured environmental variables. One-way ANOVA was used to compare the indices scores. Pearson correlation and ANOVA were performed using Palaeontological Statistics (PAST) software version 3.0 (Hammer, 2013). Canonical correlation analysis of xlstate (2014) was applied to evaluate the commulative correlation between the developed epilithic TDI- Nile and the entire entire measured environmental variable.

\section{Optima and tolerances of diatom taxa}

\section{RESULTS}

The TP and TIN optima, tolerance, indicator and senstivity value of 91 species were determined (Table 1). The epilithic tolerant and eutrophic taxa were Navicula digitoradiata, N. diluviana, N. plathii, Nitzschia paleacea and Stauroneis groenlandica var. subquadra, while the sensitive and characteristic species for oligotrophic water were Cymbella affinis, $C$. caespitosa, Gomphonema gracile and G. truncatum.

The weighted average optima of total phosphorus between epilithic communities ranged from $224.46 \mu \mathrm{gL}^{-1}$ (Navicula kriegerii) to $1275.89 \mu \mathrm{gL}^{-1}$ (Achnanthes exigua). The TP tolerance ranged from $35.73 \mu \mathrm{gL}^{-1}$ (Cymbella tumida) to $677.02 \mu \mathrm{gL}^{-1}$ (Nitzschia umbonata). Many species were mainly associated with high TP like Cocconeis placentula var. euglypta, Navicula diluviana and Neidium alpinum.

Nitzschia frustulum displayed the highest TIN optima $\left(1425.55 \mu \mathrm{gL}^{-1}\right)$. On the other hand, Rhopalodia gibba displayed the least TIN optima $\left(77.23 \mu \mathrm{gL}^{-1}\right)$. The most tolerant species for low TIN was Navicula anglica var. subsalsa which attained the least value (74.43 $\left.\mu \mathrm{gL}^{-1}\right)$, whereas Navicula accomoda tolerated the high TIN concentrations $\left(1037.8 \mu \mathrm{gL}^{-1}\right)$.

When compared with other indices (TDI in England, EPI in Italy Toronto TDI in Canada and Van Dam checklist in Netherland) the TP indicator and sensitivity values of 38 species joint with TDI, of which five species were similar in indicator and 15 in sensitivity value. 34 species of TDI-Nile were matched with EPI, of which five species were similar in indicator and 8 in sensitivity value. 27 species were coincided between TDI-Nile and Toronto TDI, of which 6 species were similar in indicator and 11 in sensitivity value, also 45 species were corresponded with van Dam list, of which 5 species were similar in indicator value as listed in Table (2). 
Mohamad S. Abd El-Karim et al.

Table 1. The epilithic taxa TP and TIN optima and tolerance with indicator and sensitivity values used in constructing the TP and TIN indices.

\begin{tabular}{|c|c|c|c|c|c|}
\hline & & & & $\operatorname{tr} m$. & \\
\hline$=$ & $\mathrm{con}$ & Nom & Ogtmin & Peternen: & $=1$ \\
\hline 1 & Nots & Aonveluterpes & mat & eño & 1 \\
\hline 2 & Nave & Achrithet wesite & $m e$ & $\operatorname{lor} \pi$ & 1 \\
\hline 2 & AOCAREDS & 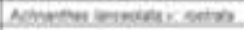 & men & $\cos \pi$ & 3 \\
\hline 1 & Aams & Advertuminms & son & thet & e \\
\hline 3 & nasroco & Acrorablytere & m.t. & see & + \\
\hline 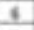 & Marewh & Anpherierent & $\min 1$ & sxis & 2 \\
\hline$t$ & Mate & Acyros ithes & $m \times 4$ & $\sin 20$ & + \\
\hline 1 & Averova & monesem. & $2 n+2$ & $280 \mathrm{~m}$ & 2 \\
\hline , & Асовен & Acporsingasts & 2010 & 560 & 3 \\
\hline ne & ANosis & Acronertort & $x=$ & 184 & is \\
\hline$n$ & MWONE K & Aropsiefs & mut & Ersta & 4 \\
\hline 9 & MUPAR & Polvermose & 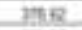 & 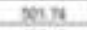 & $x$ \\
\hline 1) & CoOs. & Con moventiv & $=15$ & $\sin 20$ & 2 \\
\hline 14 & coconti: & 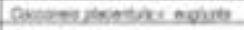 & Dit & ont & 3 \\
\hline is & croxal & Grobletohitnym & $\sin \theta$ & 120 & 4 \\
\hline * & crave & folluturessions & $A 4$ & $\operatorname{sen}$ & 3 \\
\hline 87 & Crcoc: & Grebtemeing & $4+510$ & $\operatorname{set} \theta$ & 3 \\
\hline 10 & Croors & 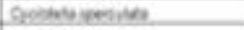 & 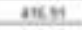 & $\sin 19$ & a \\
\hline n. & crost & Cenitatoriatyrs. & ates? & $\sin \geqslant 4$ & 2. \\
\hline$n$ & CTNAF & intmenes & 480 & $45 x$ & es \\
\hline$n$ & crener & fintmen moveren. & ose & wir & 8 \\
\hline $\boldsymbol{z}$ & cruchs & Contribrimutios & $\operatorname{sen}$ & जast & \& \\
\hline$n$ & cruts: & 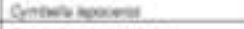 & $\sin x$ & 마로 & 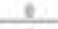 \\
\hline ze. & crues. & 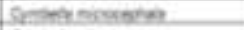 & करत & $a n$ & 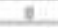 \\
\hline$\pi$ & Crosil & Gemestentst & $m n$ & $\mathrm{csin}$ & 3 \\
\hline $\mathrm{x}$ & crwive & ormorime & asil & our & 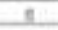 \\
\hline 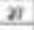 & croliven & Gontrobinitite & $m x$ & $\Leftrightarrow$ & e \\
\hline$n$ & covine & Grobmetreste & 1004 & $\cos$ & 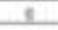 \\
\hline$\infty$ & ances. & Apumtionel: & An: & 노요 & 2 \\
\hline$\infty$ & FiNG & Eockiont & $4 B$ & $45 x$ & 2 \\
\hline$n$ & Fancon & 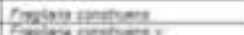 & $\sin$ & $19=$ & 3 \\
\hline$y$ & ravasons & wowes & aty & $m$ & 2 \\
\hline$n$ & Faccolanes & 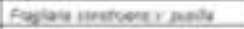 & Aft 7 & $m i n$ & 3 \\
\hline$x$ & Fhaigroes & 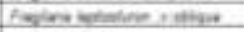 & 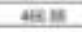 & man & 2 \\
\hline$x$ & Fhas: & Forion un & art $x$ & $\operatorname{mn}$ & 3 \\
\hline$x$ & FHoil ACY & 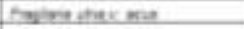 & ande & $20 x$ & 2 \\
\hline 표 & gowery & Gontorete mist & on to & $\min 10$ & 1 \\
\hline z & comais & enpiremenger & $\sin$ & met & 1 \\
\hline$\Rightarrow$ & eavolar. & entrement & $\operatorname{AES} 45$ & 모요 & 7 \\
\hline - & goven: & 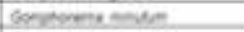 & $\sin x$ & zant & 1 \\
\hline a. & conocen & Conportenteren & 50072 & 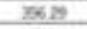 & 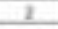 \\
\hline 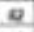 & gocuratry & Sortoretimint & $\mathrm{xen}$ & min & 4 \\
\hline s & Datia & Enpreme bists & $\operatorname{sen} x$ & me & 1 \\
\hline a & covern: & Peenomsthenen & $24 \mathrm{n}$. & 2as 8 & is \\
\hline 6 & cocosentus: & Contententeing & 200 & $20 \mathrm{~s}$ & 2 \\
\hline$=$ & arnsey & geverteverimi & Exis & Ins & 1 \\
\hline a & wichas & 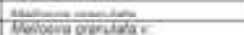 & $\operatorname{sen} n$ & $=10$ & 1 \\
\hline 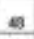 & MEL GRAMANG & orestserse & 448 & 30516 & 4 \\
\hline$a$ & Mavact & Mantidi momaroxis & $\operatorname{sen} \pi$ & seser & 4 \\
\hline 90 & Navanosus & 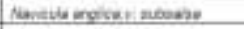 & $\operatorname{sen} 53$ & 30095 & 3 \\
\hline$s$ & NavaTS & 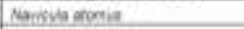 & 861,13 & $x 000$ & 2 \\
\hline$\approx$ & Mavcer & 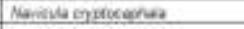 & 561.85 & 31570 & 2 \\
\hline 5) & Navros & NGonde do trostet? & 209 & 21049 & 2 \\
\hline sa & Nurot: & Naritite divivars & Sosis & $\sin x$ & 3 \\
\hline$x$ & Mavex $\times 1$ & Nantionegas & 660.42 & senes & 4 \\
\hline 5 & NUVEXXCAP & Nantide ergaser cupidts & $606 \pi$ & $200 \pi$ & 3 \\
\hline 57 & Munfiure & 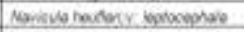 & 61201 & 20436 & 5 \\
\hline$n$ & Nanopa & Nectita itimper & 6106 & $2 \operatorname{son}$ & 0 \\
\hline$\infty$ & Marcanc & 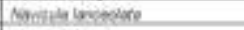 & 61524 & xat of & 2 \\
\hline$\omega$ & Mavpantiv & Nenisila pair. & Etr $x$ & $x_{1} \infty$ & $i$ \\
\hline 6) & MaVFEL & Antivepelneser & 61950 & $23 t 0 \mathrm{r}$ & 3 \\
\hline$\omega$ & Navpirir & Naritule phylests. & 6060 & 20211 & 5 \\
\hline B & NAVPLA & Nonilidapen & $63+.53$ & 2004 & 3 \\
\hline as & Navipia & Nomberase & osin & maz & 9 \\
\hline 65 & nuviead & Naritiva indena & 64521 & 20450 & 1 \\
\hline$\omega$ & Navsal & 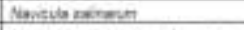 & Uate & 1000 & 1 \\
\hline 67 & NavsaL ${ }^{2}$ & 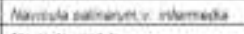 & 6005 & 10854 & 1 \\
\hline ต & NavviF: & Nerditansole & ERQ 62 & 1092 & 4 \\
\hline 69 & MUMVIPAVE & 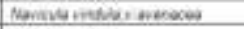 & 206 & 16503 & 3 \\
\hline$m$ & Neroup & Neture rimen & 70004 & 1000 & 3 \\
\hline$\pi$ & NEDPROO & Andur pedatetit & 73338 & 15790 & 2 \\
\hline$\pi$ & NTINE & 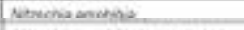 & 15860 & $18 n$ & 4 \\
\hline$n$ & MIRAPBos & 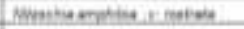 & mita & $154 \pi$ & 1 \\
\hline to & Mitosano & ingrata knoutav indis. & mat & Lat 42 & + \\
\hline 35 & MIEL & 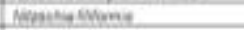 & 24174 & 14t+1. & 4 \\
\hline$\pi$ & MITICON & 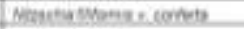 & $m+\pi$ & aE it & 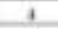 \\
\hline II & мтви & Namitahuthitem & mat & 1211 & + \\
\hline no & $\min$ & Arrasta *ureshis. & thens & mit & 2 \\
\hline$n$ & Nitses & Amprtakether & air & tols 15 & $t$ \\
\hline$m$ & Мтिні & 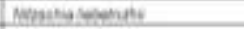 & Iitat & 1364 & 1 \\
\hline in & Netont & Amsersietint & $m a$. & 1254 & 1 \\
\hline Q & MToenan & 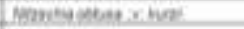 & $\tan \theta$ & 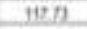 & 4 \\
\hline n & NIFA & Hithentejme & nitr & 174 & 4 \\
\hline$\omega$ & MIBALC. & Memprisoperess. & 147 & anif. & 3 \\
\hline n & mive & Armuty ictossty & $m n$ & 2118 & 4 \\
\hline w & Foocal & 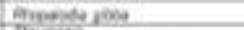 & ntom & $m e$ & t \\
\hline of & STAFAD & 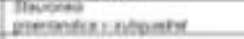 & inth & 묘. & 1 \\
\hline$m$ & srose & Grotent & $m i n$ & $54 x$ & 3. \\
\hline m. & strock & thoseuts. & एक्षित & $4 n$. & + \\
\hline is & 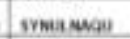 & 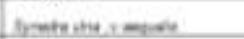 & ems & ent & $i$ \\
\hline$r$ & 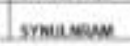 & 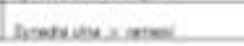 & Tüa & B) & 1 \\
\hline
\end{tabular}


Nile-Trophic Diatom Index (TDI-Nile): a new constructed index for assessment eutrophication in River Nile basine in Egypt

Table 2. Indicator (i) and Sensitivity (s) values of calculated Nile index (TDINile) for TP on epilithic substrate compared with values of TDI, EPI, Toronto TDI and Van Dam list.

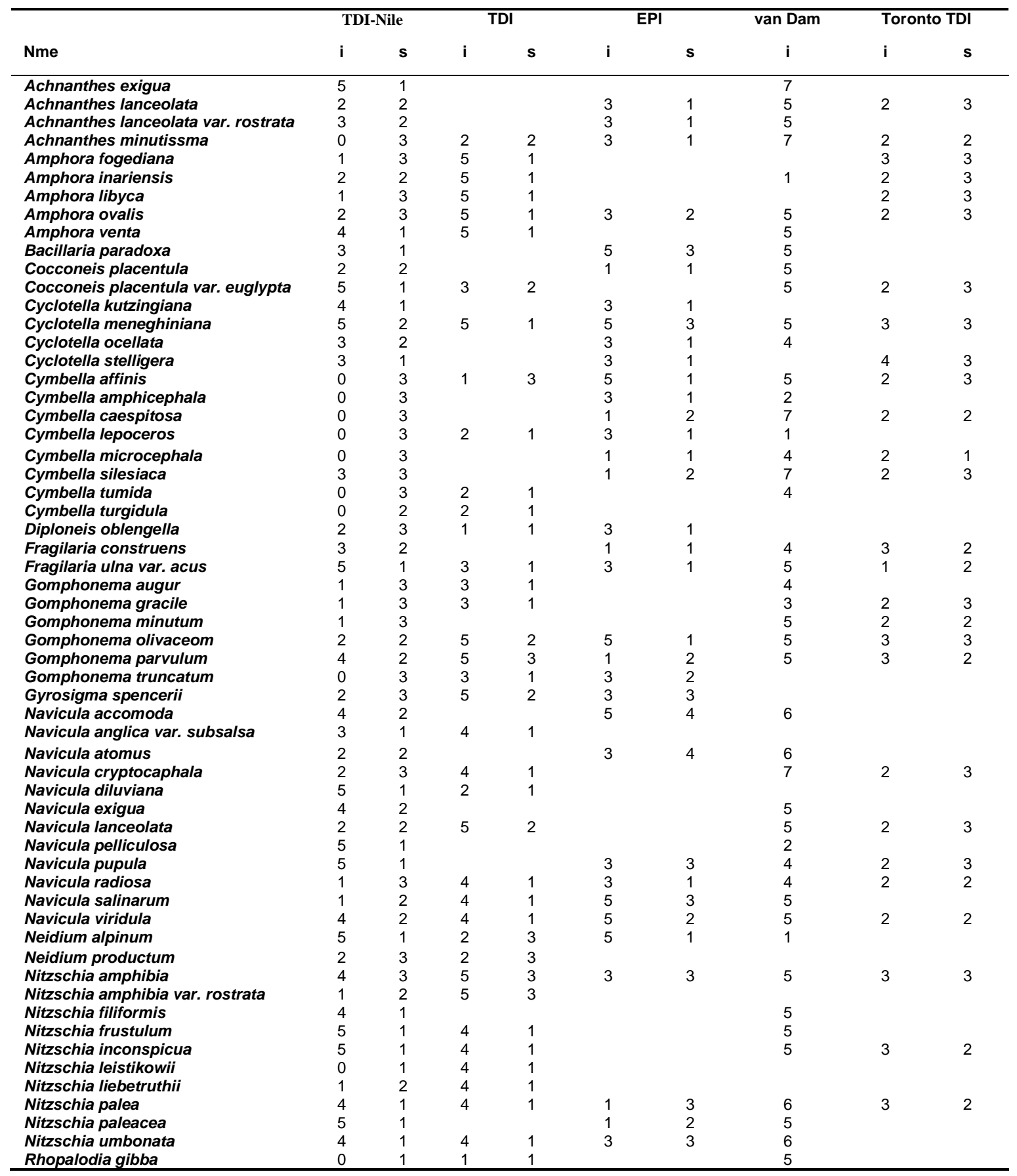




\section{Mohamad S. Abd El-Karim et al.}

\section{TDI-Nile calculation}

The species optima coefficients were rescaled from the inference model to assign as species indicator values for the diatom quality index. The indicator values were ranged from 0 (corresponding to lowest TP and TIN optima) to 5 (corresponding the highest TP and TIN coefficients). Each species was assigned a tolerance indicator value from 1(corresponding to highest TP and TIN tolerance) to 3 (corresponding to lowest TP and TIN tolerance), a sensitivity value of 3 .

The TDI-Nile scores range from 1 (very low nutrient concentrations or clean water) to 5 (very high nutrient concentrations or grossly polluted water). The TP index classified the river into 9 sites in high quality, 14 sites with good quality, 12 sites in average quality and 6 sites in bad quality. The TIN index classified 16 sites in high water quality, 17 sites in good quality, 3 sites in average quality and 5 sites in bad quality. Most of the samples which classified in bad quality were belonging to Rosetta branch and station 2 at the Kema factory in the main stem of River Nile (Fig. 1).

The index scores were compared with the measured environmental variables using a Pearson correlation matrix (Table 3). The best correlation was obtained between the two developed indices and $\mathrm{NO}_{2}, \mathrm{NH}_{4}, \mathrm{PO}_{4}, \mathrm{EC}$ and TDS. According to the canonical correlation analysis, which was used in order to evaluate the cumulative correlation between the developed TDI-Nile and the measured environmental variable, (Canonical correlation $\mathrm{r}=0.79, P<0.0001$ ). The TDI-Nile indices represent a useful tool for biomonitoring the eutrophication in the River Nile

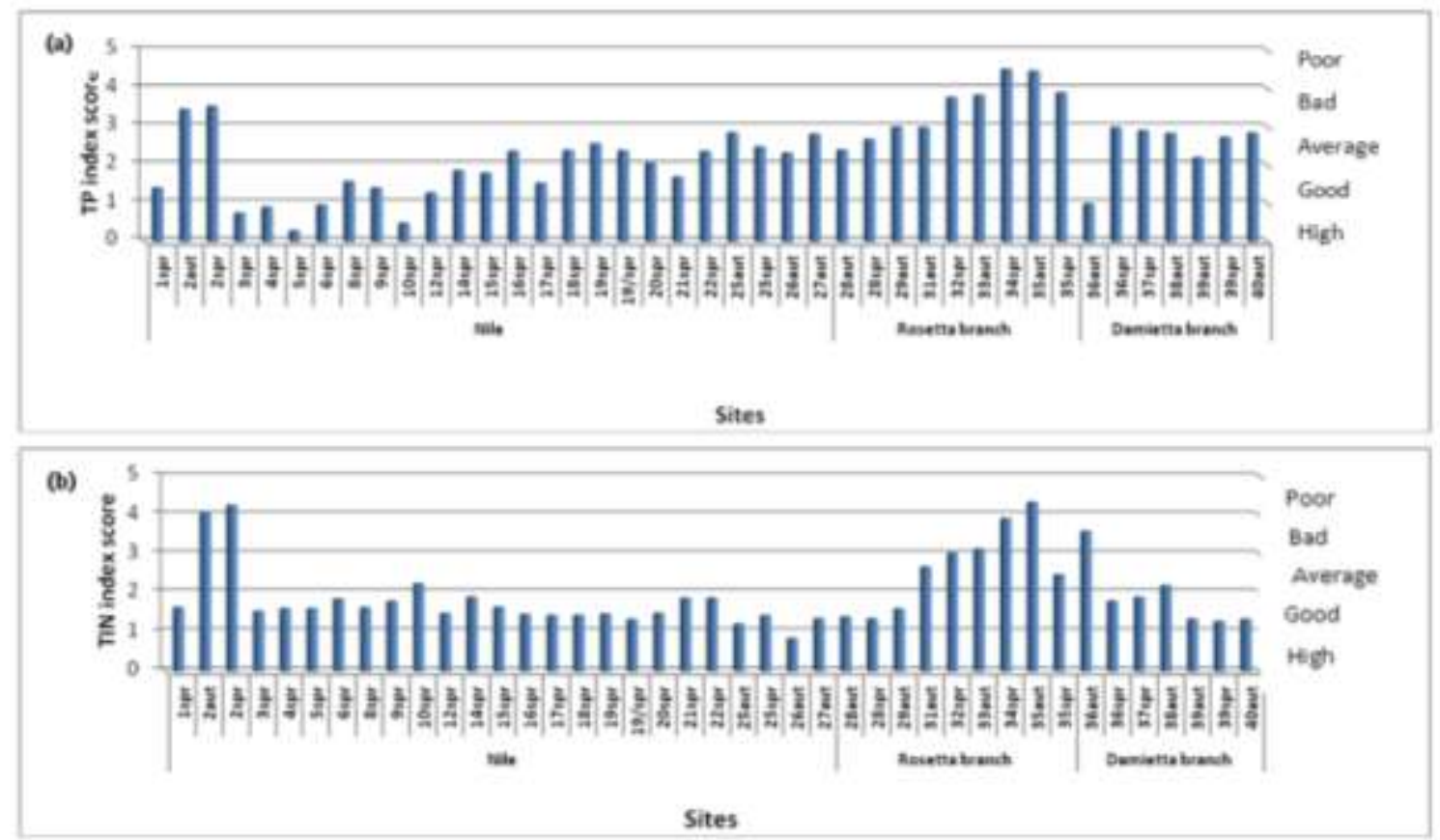

Fig. 1. Site ecological states according to TDI-Nile, a) TP index and b) TIN index 
Nile-Trophic Diatom Index (TDI-Nile): a new constructed index for assessment eutrophication in River Nile basine in Egypt

Table 3. Pearson correlation coefficients for epilithic TP and TIN indices with measured environmental variables

\begin{tabular}{|c|c|c|c|c|c|c|c|c|c|c|c|c|c|c|}
\hline Varucles: & rP noer & Towinoes & 1002 & Nos: & vets & TIN & POA & TP & sios & $P r$ & Tenp & EC & $\begin{array}{l}\text { TDS } \\
\text { mgl }\end{array}$ & $B O D$ \\
\hline TP index & 1 & & & & & & & & & & & & & \\
\hline Tw index & 0.4547 & 1 & & & & & & & & & & & & \\
\hline nos & 6.4594 & 0.4554 & 1 & & & & & & & & & & & \\
\hline 100 & -00083 & 02742 & 0.7499 & 1 & & & & & & & & & & \\
\hline Net4 & o.ses & 6. 2998 & 0.2054 & -00270 & 1 & & & & & & & & & \\
\hline Tis & 0.4013 & 0.7404 & 0.6506 & 0.5612 & 0.80a2 & I. & & & & & & & & \\
\hline POA & 0.4607 & 0.3548 & 00499 & -01010 & 0.7124 & 0,4764 & 1 & & & & & & & \\
\hline$T P$ & 0.5722 & 0.2606 & Q 1894 & -00241 & 0.6194 & 0.5050 & 0.7667 & 1 & & & & & & \\
\hline sogs & .0 .5960 & 0.0230 & -02339 & -0.019\% & ecoges & -00130 & -0.1392 & -0 2008 & $t$ & & & & & \\
\hline PAt & -02397 & -0.5945 & -0.5052 & -0.4720 & -0.4925 & -0.6267 & -62424 & - a. 18005 & Oอ7ra & 1 & & & & \\
\hline Temp & -00048 & +2093 & $0 m 2$ & 0.2745 & -0.2927 & -01560 & - ososs & .02040 & 0.0132 & -90144 & 1 & & & \\
\hline EC & 0.5545 & 0.2596 & a. $123 \mathrm{r}$ & $-0 m$ & 0.7487 & 0.9271 & อ.s7 & 0.6563 & -93500 & - 9 tsor & 0.6255 & 1 & & \\
\hline TOS ingt & 0.5545 & 0.2577 & 0.1242 & -0172 & 0.7473 & 0.5265 & 0.6774 & 0.4563 & $0.321 t$ & -01790 & - 0.4954 & 1.0060 & 1 & \\
\hline 800 & exna & -53006 & $-0,004$ & - 0911 & -0.4259 & -0.3650 & -2.1440 & -0.2406 & 0 : 941 & 0.1592 & -0.2651 & 00502 & -00494 & $t$ \\
\hline
\end{tabular}

\section{DISCUSSION}

Due to large industrial, agricultural and sewage discharges undoubtedly contribute large amounts of nutrients to Rosetta branch, high concentrations of $\mathrm{P}$ and $\mathrm{N}$ are common in sites belonging to this area of the river with the appearance of some pollution-tolerant taxa as Navicula digitoradiata,Navicula diluviana, N. plathii, Nitzschia paleacea, N. umbonata and Stauroneis groenlandica var. subquadra. Most of these taxa have a widespread distribution and consider being generalist and they can be used as indicator of poor water quality condition because they reach maximum abundance in more polluted sites (Charles et al., 2006). Most of the species which harbored an indicator value of 5 were recorded in the other compared indices; Van Dam checklist (van Dam et al., 1994), TDI (Kelly and Whitton, 1995), EPI (Dell'Uomo, 1996) and Toronto TDI (Zugic-Drakulic, 2006) and were classified in ranks of preferring eutophic and hypereutrophic water in the van Dam list and TDI. So, these species have been suggested to be found in water disturbed by input of nutrients.

When the TP indicator and sensitivity values of Nile indices compared with other indices constructed in other regions, TP indicator and sensitivity values were matched similar with few species (Table 2). However, although diatoms might have a wide geographical distribution and a globally similar ecology, their response to nutrient conditions may still be different between different ecoregions (Soininen and Niemel, 2002).

The TDI-Nile indices effectively quantify the response of the diatom flora based on the temporally and spatially integrated impacts of TP and TIN. These biotic indices simplify the complicated ecology of streams and rivers into a form that permits rapid assessment of the overall condition of a stream in a manner that is easily understood by non-technical resource managers (Gerritson, 1995). An important feature of these indices is the ability to include all diatom taxa found in the study region. Moreover, TDI-Nile differed from TDI (Kelly and Whitton, 1995), it takes into account centric diatoms, which are dominant in the River Nile, so it may perhaps perform well in rivers of high species richness of Centrales. The TP index of TDI-Nile (after compared with the Van Dam list, TDI and Toronto TDI) had higher significance correlation coefficient values than compared indices especially with $\mathrm{pH}, \mathrm{TIN}, \mathrm{TP}$ and 
Mohamad S. Abd El-Karim et al.

E.C as listed in Table (4). This comparison confirmed the successful using of the present developed indices in the biomonitoring programs of River Nile.

Table 4. Pearson correlation coefficient between different diatom indices and some measured environmental variables.

\begin{tabular}{ccccc}
\hline & TDI-Nile & Van Dam & TDI & Tronto TDI \\
\hline pH & -0.28 & -0.07 & -0.08 & -0.13 \\
TIN & $0.48\left(^{* *}\right)$ & 0.13 & 0.03 & 0.05 \\
TP & $0.57\left(^{* *}\right)$ & $0.39\left(^{*}\right)$ & 0.13 & $0.44\left(^{*}\right)$ \\
E.C & $0.55\left(^{* *}\right)$ & $0.47\left(^{*}\right)$ & 0.004 & $0.45\left(^{*}\right)$ \\
\hline
\end{tabular}

$(* *)$ Correlation is significant at the $<0.003$ level

(*) Correlation is significant at the 0.01 level

The developed indices in the present study characterize a wide range of water quality in the River Nile and the obtained results agreed well with the degree of pollution indicated by physical and chemical variables and with the combined effects of these factors (Canonical correlation $\mathrm{r}=0.79, P<0.0001$ ).

These developed indices based on two variables, TP and TIN which simply signify the percentage of eutrophication. However, the ratios of the dissolved inorganic nitrogen to TP are better indicators of nutrient limitation in oligotrophic water. This suggests that DIN metrics may provide better measures of $\mathrm{N}$ requirements, and would be useful to add in future studies (Bergstrom, 2010).

\section{REFERENCES}

Abd El-Karim, M.; Khafagi, O. and Bela, D. (2016). Effect of substrate type on the response of diatoms to environmental gradients: Implication for bioassessment and biomonitoring programs. Int. J. Fish. \& Aquat. Stud., 4(2): 361-369

ANS, The Academy of Natural Sciences (2002). Protocols for the analysis of algal samples collected as part of the U.S. Geological Survey National Water-Quality Assessment Program, 02-06.

APHA, American Public Health Association (2005). Standard Methods for the Examination of Water and Wastewater. $21^{\text {th }}$ ed. Washington, D.C. $1220 \mathrm{p}$.

Atazadeh, I.; Sharifi, M. and Kelly, M. (2007). Evaluation of the trophic diatom index for assessing water quality in River Gharasou. Western Iran. Hydrobiologia, 589: 165-173.

Belal, D. (2012). Epipelic diatoms as a tool for monitoring pollution in River Nile from Aswan to Cairo. M.Sc. Thesis. Faculty of Science, Cairo Univ, Egypt, $109 \mathrm{p}$.

Bergstrom, A. (2010). The use of TN:TP and DIN: TP ratios as indictors for phytoplankton nutrient limitation in oligotrophic lakes affected by atmospheric $\mathrm{N}$ deposition. Aquat. Sci., 72: 277-281.

Birks, H.; Line, J.; Juggins, S.; Stevenson, A. and Ter Braak, C. (1990). Diatoms and $\mathrm{pH}$ reconstruction. Philisophical Transactions of the Royal Society of London, 327 (1240): 263-278.

Cemagref (1982). Etude des methodes biologiques quantitative d'appreciation de la qualite des eaux . Rapport Division Quaite des Eaux Lyon - Agence de l'Eau Rhone - Mediteranee - Corse, Pierre - Benite, 28 pp.

Charles, D.; Acker, F.; Hart, D.; Reimer, C. and Cotter, P. (2006). Large-scale regional variation in diatom-water chemistry relationships: rivers of the eastern United States, Hydrobiologia; 561: 27-57. 

eutrophication in River Nile basine in Egypt

Chessman, B.; Growns, I.; Currey, J. and Plunkett-Cole, N. (1999). Predicting diatom communities at the genus level for the rapid biological assessment of rivers. Freshwater Biol., 41: 317-331.

Dell'Uomo, A. (1996). Assessment of water quality of an Apennine river as a pilot study. In: Whitton B. A. and Rott? initials(eds.) Use of Algae for Monitoring Rivers II. Institut für Botanik. Universitat Innsbruck, 65-73 pp.

Descy, J. (1979). A new approach to water quality estimation using diatoms. Nova Hedwigia, 64: 305-323.

Gerritson, J. (1995). Additive biological indices for resource management. Journal of the North American Benthological Society, 14: 451-457.

Hammer, O. (2013). Past-Palaeontological Statistics, version 3.0. At. http://folk.uio.no/ohammer/past.

Juggins, S. (2003). C2 User guide-Software for ecological and paleoecological analysis and visualization, version 1.7.3. University of Newcastle, Newcastle upon Tyne, U.K., 69 pp.

Karr, J. and Chu, E. (2000). Sustaining living rivers. Hydrobiologia; 422/423: 1-14.

Kelly, M. and Whitton, B. (1995). The trophic diatom index: a new index for monitoring eutrophication in rivers. J. Appl. Phycol., 7: 433-444.

Lenoir, A. and Coste, M. (1996). Development of a practical diatomic index of overall water quality applicable to the French National Water Board Network. In: Rott, E. (ed.) 2nd Workshop on Algae for Monitoring Rivers, Innsbruck 1819 Sept. 95, Studia Student. G.m.b.H., Innsbruck.

Niemi, G. and McDonald, M. (2004). Application of ecological indicators. Annu. Rev. Ecol. Evol. Syst., 35:89-111

Potapova, M. and Charles, D. (2007). Diatom metrics for monitoring eutrophication in rivers of the United States. Ecological Indicators, 7: 48-70.

Prygiel, J.; Whitton, B. and Bukowska, J. (1999). Use of algae for monitoring rivers III. Agence de l'Eau Artois-Picardie, Douai, France, 271pp.

Radar, R. and Shiozawa, D. (2001). General principles of establishing a bioassessment program. In Bioassessment and management of North American freshwater wetlands, R.B. Radar, D.P. Batzer, and S.A. Wissinger, eds. New York, NY: John Wiley and Sons, Inc. pp. 13-43.

Rumeau, A. and Coste, M . (1988). Initiation a la systematique des diatomees d'eau douce pour ('utilisation pratique d'un indice diatomique generique). Bulletin Francais de la Peche et de la Pisciculture; 309: 1-69.

Seegert, G. (2001). The development, use, and misuse of biocriteria with and emphasis on index of biotic integrity. Environ. Sci. \& Pollut. Res., 3: 51-58.

Sladecek, V. (1986). Diatoms as indicators of organic pollution. Acta Hydrochimica et Hydrobiologics, 14(5): 555-566.

Soininen, J. and Niemel, P. (2002). Inferring the phosphorus levels of rivers from benthic diatoms using weighted averaging. Archiv fur Hydrobiologie, 154: 1-18.

Stevenson, R. and Smol, J. (2002). Use of algae in environmental assessment. In: Wehr, J.D., Sheath, R.G. (Eds.), Freshwater Algae of North America: Ecology and Classification.Academic Press, New York, pp. 775-804.

Taylor, J.; Prygiel, J.; Vosloo, A.; de la Rey P. and van Rensburg, L. (2007). Can diatom-based pollution indices be used for biomonitoring in South Africa? A case study of the Crocodile West and Marico water management area. Hydrobiologia, 592: 455-464. 
